\title{
The Characterization of Indonesian's Natural Zeolite For Water Filtration System
}

\author{
Mirzan T. Razzak ${ }^{1,2} *$, Thamzil Las ${ }^{2}$, Priyambodo ${ }^{1}$ \\ ${ }^{1}$ Center for Integrated Laboratory, ${ }^{2}$ Faculty of Science and Technology \\ State Islamic University of Syarif Hidayatullah Jakarta 15412 \\ *Email: mirzan_razzak@uinjkt.ac.id
}

\begin{abstract}
The characterization of Indonesian's natural zeolite for water purification has been done. The objective is to obtain a general guidance for development of natural zeolite in molecular sieves, ion exchange and catalyst applications. The zeolites originated from Lampung (ZL) was characterized by using XRD. It was found that the zeolites indicate belong to clinoptilatite and mordenite groups, respectively. The crystal system for ZL was monoclinic with end-centered lattice and space group of $\mathrm{Cm} / 2$ (12). The crystal system for $\mathrm{ZB}$ was orthorhombic with endcentered lattice and space group of $\mathrm{CmC} 21$ (36). The character of both zeolites were confirm by ICDD standard library. It was also found that the particle size of zeolites did not affect the XRD spectra where zeolite of 40-50 mesh was similar to that XRD spectra of zeolite of 170-200 mesh. The chemical analyses show that both zeolites contain almost similar chemical elements. The contents of $\mathrm{Fe}, \mathrm{Ca}$, and $\mathrm{K}$ were found higher in $\mathrm{ZL}$ as it is compared to $\mathrm{ZB}$. Reciprocally, Na was found higher in $\mathrm{ZB}$. The water filtration ability shows that $\mathrm{ZB}$ was better than $\mathrm{ZL}$ for filtering of $\mathrm{Pb}$ and Fe elements. These ability were improved by chemical activation of zeolites. These two zeolites, howover, behave similar less ability for the filtering of $\mathrm{Ca}$ and $\mathrm{Mg}$ elements due to that elements probably were originally exist in the zeolite structure. These characterization is necessary to designing a further development of natural zeolite applications.
\end{abstract}

Keywords : natural zeolite, clinoptilolite, mordenite, $\mathrm{x}$-ray diffraction, water filter

\begin{abstract}
Abstrak
Telah dilakukan karakterisasi zeolit alam Indonesia untuk pembuatan sistem penjernihan air. Zeolit alam yang didapat dari Lampung (ZL) dan Banten (ZB) dikarakterisasi dengan X-Ray Diffractometer (XRD) dan diuji kemampuannya untuk penjernihan air. Tujuan penelitian ini adalah untuk mengembangkan pemanfaatan zeolit alam sebagai penyaring molekuler (molecular sieve), penukar ion maupun sebagai katalis. Pengukuran XRD menunjukkan bahwa zeolit alam yang berasal dari Lampung termasuk jenis klinoptilolit dengan sistem kristal monoklinik, jenis kisi end-centered, dan groupCm/2 (12). Sedangkan yang berasal dari Banten termasuk jenis mordenit dengan sistem kristal orthorhombic, jenis kisi end-centered, dan group Cmc21 (36). Dari penelitian ini diketahui juga bahwa ukuran zeolit alam tidak mempengaruhi bentuk pola spektrum XRD. Analisa kimia menunjukkan bahwa kedua jenis zeolit tersebut mengandung unsur kimia yang sama. Kadar unsur Fe, Ca, dan K didapatkan lebih tinggi terkandung dalam ZL. Sebaliknya kadar unsur $\mathrm{Na}$ lebih tinggi dalam $\mathrm{ZB}$. Kemampuan penyaringan $\mathrm{Pb}$ dan Fe didapatkan lebih baik pada ZB. Kemampuan ini dapat ditingkatkan bila zeolit terlebih dahulu diaktivasi secara kimia. Namun demikian baik ZL maupun ZB mempunyai kemampuan penyaringan $\mathrm{Ca}$ dan $\mathrm{Mg}$ yang sangat rendah, yang mungkin disebabkan oleh karakteristik unsur tersebut. Karakteristik ini sangat berguna untuk perancangan dan pengembangan aplikasi ZL dan ZB ke depan.
\end{abstract}

Kata kunci: zeolit alam, klinoptilolit, mordenit, difraksi sinar-x, filter air.

\section{INTRODUCTION}

Indonesia is carrying out different research work in order to improve the natural resources utilization. It was understood that the higher utilization of natural resources make higher contribution to natural development. In this work, natural zeolites which are abundance available in Indonesian wish to be developed to achieve a more added value materials such as water purification/filtration system. 
In fact, the natural zeolites have been used in agriculture as soil conditioner, as component of fertilizer, animal feed as well as a neutralization agent for bad smell waste (Thamzil \& Husen, 1999) (Supandi, 1999). The applications of zeolite in engineering are still very few. Some research were done to develop zeolites for its application as water filtration or as membrane system (Xiaochun, et al., 2004) (Worathanakul \& Kongkachuichay, 2008) (Valentine, 2009) (Jie, et al., 2002).

According to various researches, zeolite mainly a synthetic ores may have a great potential as membrane system such as micro filtration (MF), ultra filtration (UF), ad reverse osmosis (RO) as well as a powerful catalyst, ion exchanger, and gas separation systems (Berrin, 2008) (Stankov, et al., 2003) (Drew Chemical Corporation, 1967) (Kaseno, 1999) (Hadiati, 1999) (Lanjar, 1999) (Takao,1999).

In fact, however the researches for the utilization of natural zeolites are still low due to some reasons. Among of that reasons were the variety of character of natural zeolites. Two sources of natural zeolite, i.e. originated from Lampung (ZL) and originated from Bayah, Banten (ZB) are used to be characterization in the present work. The characterizations of two zeolites were carried out using $\mathrm{x}$-ray diffractometer (XRD) instrument.

The objectives of this work is to obtain a general orientation of zeolite's crystal system, its properties as well as to determine a selective elements that probably affecting in the character of natural zeolite for its application as water filtration system.

\section{MATERIALS AND METHOD}

\section{Materials}

Natural zeolite were supplied by PT Minamata Mineral Perdana, i.e. originated from Lampung (ZL), and by volunteer zeolite mining agency, i.e. originated from Bayah, Banten (ZB). The zeolites were treated by ball milling and sieved to obtain a homogeneous powder size of 40-200 mesh, before used. Some necessary chemicals were used as a zeolite binder or as chemical activation agent.

\section{Instruments}

Shimadzu X-Ray Diffractometer instrument type 7000 made in Japan was used to characterization of crystal system. The instrument was first calibrating using silicon standard. Perkin Elmer Atomic Absorption Spectrometer (AAS) type AAnalyst 700, made in USA was used to analyze chemical elements. Other equipments such Memmert Oven (Germany) and Vulcon Kiln type 550 (Germany) were used for drying and sintering work. Various tools, beaker glass and plastic equipments were used as necessary.

\section{Zeolite Activation}

The chemical activation of zeolite were done as follows:

$50 \mathrm{gr}$ of zeolites was kept in $\mathrm{HCl} 2 \mathrm{M}$ solution for one hour, washed and decanted by aquadest until neutral $(\mathrm{pH}=7.0)$. It was, they kept in $\mathrm{NaNO}_{3} 2 \mathrm{M}$ solution for 1 hour, washed and decanted adequately by aquadest until neutral, and then dried in oven at $105^{\circ} \mathrm{C}$ until a constant weight.

\section{XRD Characterization}

Natural zeolite powder sample was put into a sample holder appropriately, kept homogeneous surface and placed it at measurement position. The measurement was done according to computer operating system and the obtained XRD spectrum was recorded. It took about 45 minute for each sample measurement. The obtained XRD spectrum was evaluated by standard diffraction data of $\mathrm{x}$-ray from ICDD (International Centre for Diffraction Data).

\section{AAS Measurement}

0.5 gr of zeolite sample was destructed by aqua regia $\left(\mathrm{HCl}+\mathrm{HNO}_{3}\right)$, diluted to $100 \mathrm{ml}$ by distilled water and arrange the concentration to be appropriate for AAS measurement. The measurement was done by flame detector technique and the results were computerized recorded and print-out as necessary.

\section{Filter Preparation}

The zeolite sample was poured into a glass column (dia. $3 \mathrm{~cm}$ ) for $5 \mathrm{~cm}$ thickness for media zeolite bed. The zeolite sample may be 40-200 mesh zeolite powder or a chemical activation zeolite. The media zeolite bed ability in filtering of different solution of $\mathrm{Pb}$ acetate $(0.2 \mathrm{M}), \mathrm{FeCl}_{3}(0.1 \mathrm{M}), \mathrm{MgSO}_{4}(1.0$ $\mathrm{M})$, and $\mathrm{CaCl}_{2}(0.2 \mathrm{M})$ were observed. The filtrate was measured by AAS after a necessary 
dilution. The contents of $\mathrm{Pb}, \mathrm{Fe}, \mathrm{Mg}$, and $\mathrm{Ca}$ either in filtrate and remain in media zeolite bed was evaluated. The filtering capability of natural zeolite that was prepared by a binder was also investigated.

\section{RESULTS AND DISCUSSION}

\section{XRD of Lampung Zeolite (ZL)}

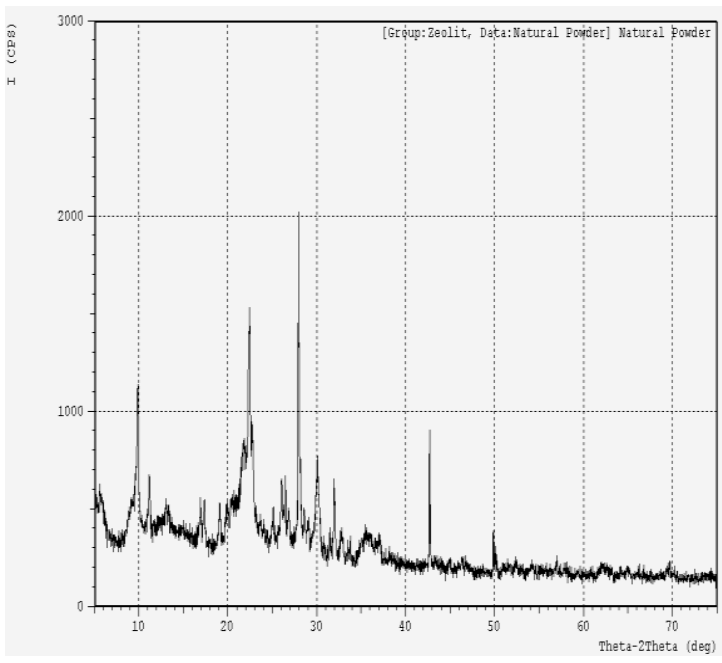

Fig.1. XRD Spectrum of Lampung Zeolit.

Figure 1 shows the XRD Spectrum of Lampung zeolite. As can be seen in Fig.1, there are 3 strongest peaks, followed by another 3 weaker peaks. The position of the six peaks can be summarized in Fig. 2, and it details can be seen in Table 1. In Table 1, the strongest 3 peaks were found at $2 \theta$ of $27.9583^{\circ}, 22.3963^{\circ}$, and $9.8631^{\circ}$ where the ratio of $\mathrm{I} / \mathrm{I}_{0}$ were 100,54 , and 39 respectively. Another 3 peaks were found at $2 \theta$ of $42.6835^{\circ}$, $30.0600^{\circ}$, and $31.9600^{\circ}$ where the ratio of $\mathrm{I} / \mathrm{I}_{0}$ were $38 ; 27$; and 21 , respectively.

According to ICDD 47-1870 data library, the existence of the strongest peaks

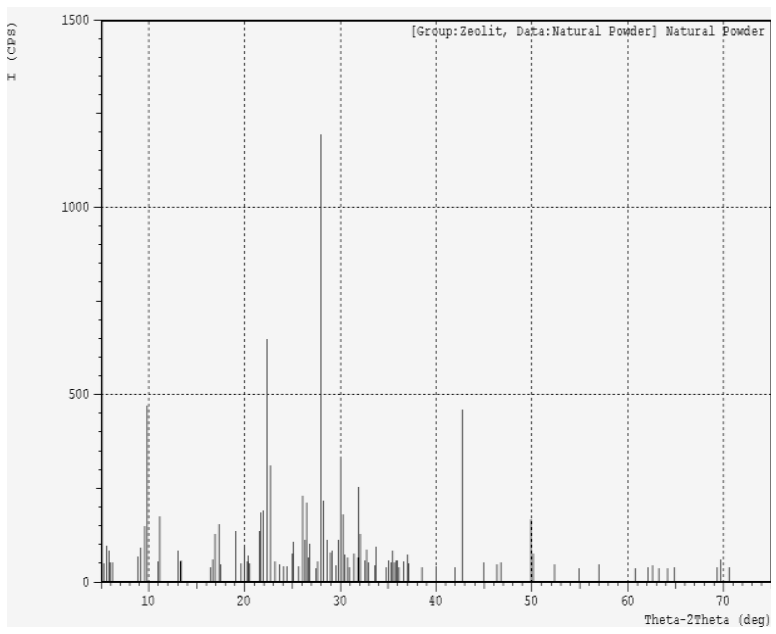

Fig.2. XRD Spectrum Line of Lampung Zeolit.

may indicate that the mineral was appropriate with potassium sodium calcium aluminum silicate hydrate of clinoptilolite-Na.

Based on Bravais classification crystal system, it was found to be a base-centered monoclinic, with a lattice of end-centered and the space group of $\mathrm{C} 2 / \mathrm{m}$ (12).

Accordingly,there are three unequal axes, one pair not at right angle, $\mathrm{a} \neq \mathrm{b} \neq \mathrm{c}, \alpha=$ $\gamma=90^{\circ}$ and $\beta \neq 90^{\circ}$ [14]. The crystal system can be illustrated as the following figure (See Fig.3).

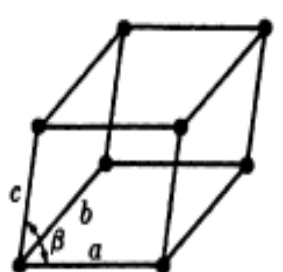

Primitive $(\mathrm{P})$

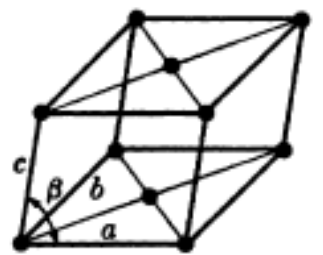

End-centered (C)
Fig.3. Bravais lattice for monoclinic crystal system.

Tabel 1. The Strongest Peaks of XRD Spectrum of Lampung Zeolite (Powder)

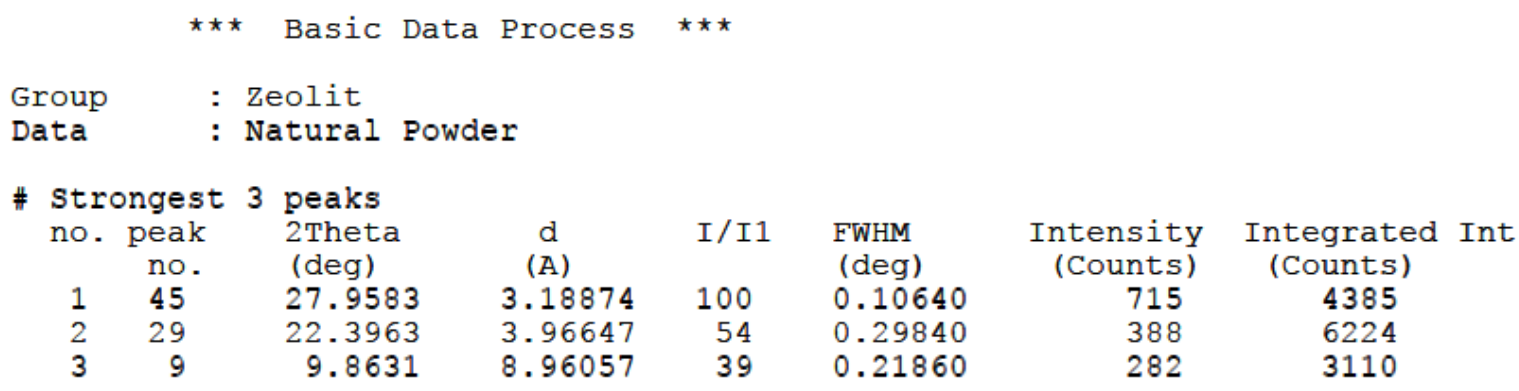


Tabel 2. ICDD Data for 47-1870

ICDD 47-1870

Mineral : Clinoptilolite-Na

Potassium Sodium Calcium Aluminum Silicate Hydrate

Chemical

: $[\mathrm{Na}, \mathrm{K}, \mathrm{Ca}]_{5} \mathrm{Al}_{6} \mathrm{Si}_{30} \mathrm{O}_{72} .18 \mathrm{H}_{2} \mathrm{O}$

\begin{tabular}{|l|l|l|l|l|l|l|l|}
\hline Crystal System & Monoclinic & Space Group & C2/m (12) & a & 17,647 & $\boldsymbol{\alpha}$ & 90 \\
\hline Lattice & End-centered & Density & 2.046 & b & 18,007 & $\beta$ & 116.3 \\
\hline Lambda & 1,5406 & Pattern & I & c & 7,396 & $\gamma$ & 90 \\
\hline
\end{tabular}

The data indicate that the crystal structure should belong to a clinoptilolite, its density of $2.16 \mathrm{~g} / \mathrm{mol}$ and a unit cell volume of $2100 \AA$. These agreed to description that was reported by Thamzil Las (Ph.D. Thesis) [15]. The unit cell may have a dimensions of $\mathrm{a}=7.41$ $\AA, b=17.89 \AA$, and $c=15.85 \AA$. If the data are compared to that ICDD library, then it seems to be the same. In orher word, the ZL could be predicted behave a crystal structure belong clinoptilolite group. The chemical formula of clinoptilolite is assumed to be $\mathrm{Na}_{6}\left[\left(\mathrm{AlO}_{2}\right) 6\right.$ $\left.\left(\mathrm{SiO}_{2}\right)_{30}\right] 24 \mathrm{H}_{2} \mathrm{O}$.

In ICDD 47-1870 data, the clinoptilolite-Na may contains of $[\mathrm{Na}, \mathrm{K}, \mathrm{Ca}]_{5}$ $\mathrm{Al}_{6} \mathrm{Si}_{30} \mathrm{O}_{72} .18 \mathrm{H}_{2} \mathrm{O}$ as can be seen in Table 2 .

It can be concluded therefore, that the observed zeolite (ZL) should be a clinoptilolite with a monoclinic crystal system.

Further XRD measurement of ZL with different mesh has shown the same pattern of XRD spectrum. The strongest peaks was given at $2 \theta$ of $28.0520^{\circ}$ followed by the second strongest at $2 \theta$ of $22.3963^{\circ}$. (See Table 3)

From Table 3, the peaks of XRD spectrum at $2 \theta$ of $28.0520^{\circ}$ and $22.3963^{\circ}$ may be estimated as peaks character for natural zeolite of ZL. In fact, the XRD spectrum of ZL do not affected by the particle size, since the two XRD spectrum of ZL show the similar pattern.

\section{XRD of Activated Lampung Zeolite (ZL)}

Fig. 4 shows the XRD spectrum of activated zeolite ZL. As can be seen in Fig. 4, there are three other strong peaks i.e. at $2 \theta$ of $42.2126^{\circ}, 31.4545^{\circ}$, and $51.4774^{\circ}$ beside of three peaks that were assumed to be characterization's peaks of clinoptilolite. Actually, the three other strong peaks have also available in XRD spectrum pattern of previously $\mathrm{ZL}$, but in the form of weaker peaks.

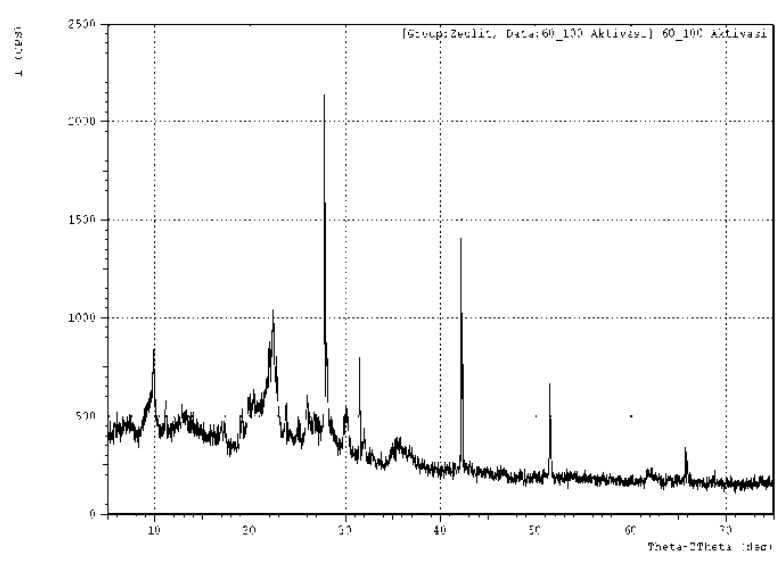

Fig.4. XRD spectrum of activated Lampung zeolit.

Perhaps a higher peak at $2 \theta$ of $42.2126^{\circ}$ as its compared to that previously ZL was caused by sodium cation that coming from activation process. If it's true, it can be predicted that activated ZL may containing a single cation of $\mathrm{Na}$. Therefore, the activation of zeolite can be favorable for molecular siever as well as for cation exchanger.

\section{XRD of Bayah, Banten Zeolite}

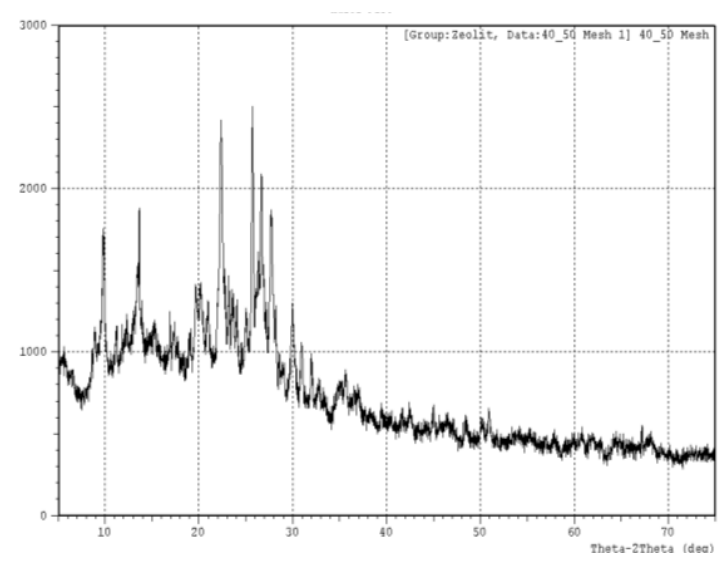

Fig.5. XRD Spectrum of Bayah, Banten Zeolit (40-50 mesh) 
Fig. 5 shows the XRD spectrum of Bayah, Banten zeolite (ZB) of particle size of 40-50 mesh. As can be seen in Fig.5, there are three strongest peaks available i.e. peak at $2 \theta$ of $25.6897^{\circ}(100), 27.3619^{\circ}$ (95), and $26.6704^{\circ}$ (77). Other strong peaks were shown at $2 \theta$ of $27.7185^{\circ}(68), 9.8023^{\circ}(62)$, and $13.6000^{\circ}$ (51). All the peaks may be assumed as a characteristic XRD spectrum of ZB. Detail data of XRD spectrum of $\mathrm{ZB}$ are presented in Table 4.

Tabel 4. The Strongest Peaks of XRD Spectrum of Bayah, Banten Zeolite (40-50 mesh)

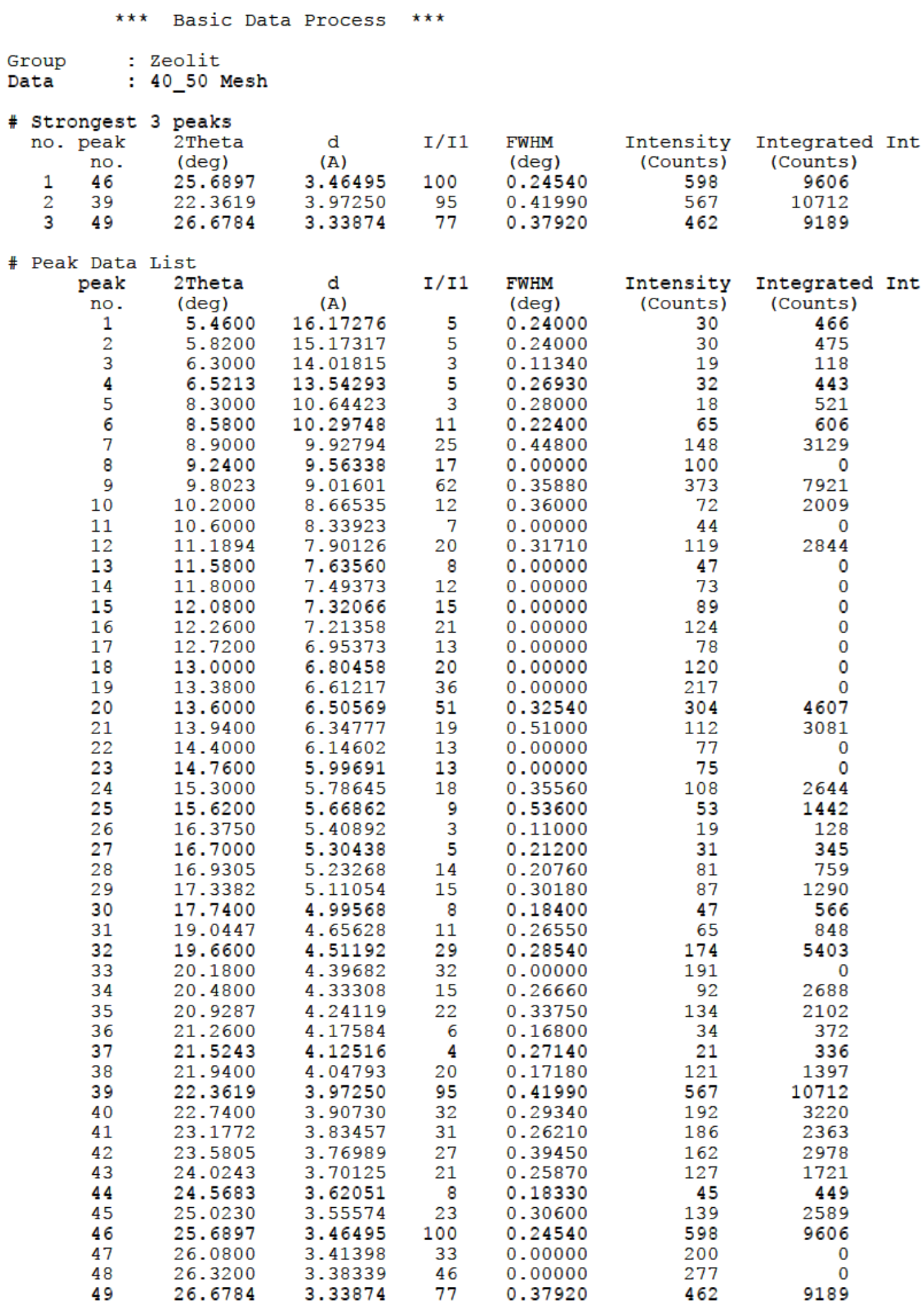




\begin{tabular}{|c|c|c|c|c|c|c|}
\hline $\begin{array}{l}\text { peak } \\
\text { no. }\end{array}$ & $\begin{array}{l}\text { 2Theta } \\
\text { (deg) }\end{array}$ & $\underset{(\mathrm{A})}{\mathrm{d}}$ & I/I1 & $\begin{array}{l}\text { FWHM } \\
\text { (deg) }\end{array}$ & $\begin{array}{l}\text { Intensity } \\
\text { (Counts) }\end{array}$ & $\begin{array}{c}\text { Integrated } \\
\text { (Counts) }\end{array}$ \\
\hline 50 & 26.9000 & 3.31174 & 37 & 0.00000 & 223 & 0 \\
\hline 51 & 27.1400 & 3.28300 & 26 & 0.29660 & 158 & 3356 \\
\hline 52 & 27.7185 & 3.21578 & 68 & 0.39370 & 407 & 7308 \\
\hline 53 & 28.1200 & 3.17077 & 25 & 0.29840 & 150 & 2474 \\
\hline 54 & 28.5771 & 3.12108 & 11 & 0.21580 & 67 & 699 \\
\hline 55 & 28.9218 & 3.08466 & 7 & 0.36360 & 44 & 740 \\
\hline 56 & 29.5800 & 3. 01751 & 4 & 0.12000 & 23 & 212 \\
\hline 57 & 29.9533 & 2.98074 & 33 & 0.36670 & 199 & 3591 \\
\hline 58 & 30.3600 & 2.94173 & 7 & 0.16000 & 43 & 585 \\
\hline 59 & 30.9271 & 2.88907 & 22 & 0.27580 & 131 & 1869 \\
\hline 60 & 31.9783 & 2.79646 & 19 & 0.23420 & 113 & 1387 \\
\hline 61 & 32.3622 & 2.76416 & 3 & 0.07560 & 20 & 93 \\
\hline 62 & 32.7636 & 2.73120 & 9 & 0.31270 & 54 & 960 \\
\hline 63 & 33.2928 & 2.68899 & 4 & 0.34570 & 25 & 469 \\
\hline 64 & 34.4414 & 2.60190 & 6 & 0.15710 & 33 & 298 \\
\hline 65 & 34.7200 & 2.58165 & 11 & 0.16000 & 63 & 1343 \\
\hline 66 & 35.0600 & 2.55739 & 13 & 0.00000 & 75 & 0 \\
\hline 67 & 35.2600 & 2.54334 & 10 & 0.00000 & 59 & 0 \\
\hline 68 & 35.6290 & 2.51784 & 18 & 0.33800 & 106 & 2145 \\
\hline 69 & 36.1000 & 2.48607 & 6 & 0.26800 & 38 & 499 \\
\hline 70 & 36.5800 & 2.45454 & 10 & 0.52000 & 61 & 1272 \\
\hline 71 & 37.0000 & 2.42764 & 11 & 0.28660 & 64 & 972 \\
\hline 72 & 37.6340 & 2.38818 & 4 & 0.17200 & 21 & 231 \\
\hline 73 & 38.2353 & 2.35200 & 3 & 0.26070 & 18 & 290 \\
\hline 74 & 39.4493 & 2.28237 & 6 & 0.20530 & 37 & 427 \\
\hline 75 & 40.3950 & 2.23109 & 5 & 0.29000 & 27 & 469 \\
\hline 76 & 41.6551 & 2.16646 & 8 & 0.20170 & 46 & 592 \\
\hline 77 & 41.9512 & 2.15185 & 5 & 0.13750 & 27 & 207 \\
\hline 78 & 42.2400 & 2.13781 & 4 & 0.13600 & 26 & 180 \\
\hline 79 & 42.4650 & 2.12700 & 9 & 0.31000 & 51 & 650 \\
\hline 80 & 42.7200 & 2.11489 & 4 & 0.12000 & 22 & 157 \\
\hline 81 & 44.0766 & 2.05289 & 4 & 0.27330 & 21 & 411 \\
\hline 82 & 44.9573 & 2.01470 & 10 & 0.29740 & 58 & 947 \\
\hline 83 & 45.6725 & 1.98480 & 5 & 0.21500 & 30 & 357 \\
\hline 84 & 45.9000 & 1.97549 & 5 & 0.26000 & 27 & 281 \\
\hline 85 & 46.2000 & 1.96336 & 5 & 0.22660 & 32 & 290 \\
\hline 86 & 46.4200 & 1.95457 & 8 & 0.42400 & 48 & 950 \\
\hline 87 & 46.8000 & 1.93958 & 5 & 0.00000 & 29 & 0 \\
\hline 88 & 47.0483 & 1.92992 & 6 & 0.20330 & 36 & 595 \\
\hline 89 & 48.4315 & 1.87798 & 9 & 0.27190 & 55 & 881 \\
\hline 90 & 50.0600 & 1.82064 & 8 & 0.21140 & 50 & 530 \\
\hline 91 & 50.3200 & 1.81184 & 6 & 0.21500 & 38 & 471 \\
\hline 92 & 50.8984 & 1.79260 & 12 & 0.25190 & 74 & 1148 \\
\hline 93 & 53.4125 & 1.71400 & 5 & 0.20500 & 32 & 414 \\
\hline 94 & 53.8000 & 1.70257 & 3 & 0.32000 & 19 & 374 \\
\hline 95 & 54.0000 & 1.69673 & 4 & 0.00000 & 23 & 0 \\
\hline 96 & 54.1950 & 1.69109 & 6 & 0.23000 & 34 & 528 \\
\hline 97 & 55.2571 & 1.66107 & 6 & 0.23430 & 36 & 643 \\
\hline 98 & 55.6566 & 1.65009 & 4 & 0.23330 & 23 & 347 \\
\hline 99 & 56.9650 & 1.61526 & 5 & 0.17000 & 28 & 311 \\
\hline 100 & 57.8200 & 1.59339 & 6 & 0.22000 & 37 & 536 \\
\hline 101 & 59.8000 & 1.54527 & 5 & 0.28000 & 31 & 461 \\
\hline 102 & 59.9800 & 1.54107 & 4 & 0.28000 & 25 & 369 \\
\hline 103 & 60.2400 & 1.53503 & 3 & 0.00000 & 20 & 0 \\
\hline 104 & 60.5200 & 1.52860 & 4 & 0.00000 & 26 & 0 \\
\hline 105 & 60.7800 & 1.52268 & 8 & 0.36000 & 47 & 631 \\
\hline 106 & 60.9400 & 1.51907 & 5 & 0.29720 & 32 & 325 \\
\hline 107 & 61.3672 & 1.50951 & 3 & 0.08780 & 18 & 101 \\
\hline 108 & 61.6318 & 1.50367 & 7 & 0.20640 & 44 & 422 \\
\hline 109 & 61.9400 & 1.49692 & 8 & 0.28000 & 50 & 825 \\
\hline 110 & 62.2800 & 1.48956 & 4 & 0.00000 & 24 & 0 \\
\hline 111 & 62.5200 & 1.48442 & 4 & 0.00000 & 21 & 0 \\
\hline
\end{tabular}

The measurement of XRD spectrum of ZB for different particle size of 170-200 mesh results the same XRD spectrum pattern. The XRD spectrum of ZB which has particle size of 170200 mesh shows three strongest peaks at $2 \theta$ of $25.780^{\circ}(100), 22.382^{\circ}$ (78), and $9.761^{\circ}$ (54) and these similar to that XRD spectrum of other particle size of ZB. Therefore, the particle size of zeolite may concluded do not affect the pattern of XRD spectrum. Table 5 shows ICDD data for 49-0924 
Tabel 5. ICDD Data for 49-0924

ICDD 49-0924

Mineral : Mordenite, syn

Sodium Aluminum Silicate - Zeolite Al-modenite

Chemical $\quad: \mathrm{Na}_{2} \mathrm{Al}_{2} \mathrm{Si}_{13.3} \mathrm{O}_{29.6}+\mathrm{x}$

\begin{tabular}{|l|l|l|l|l|l|l|l|}
\hline Crystal System & Orthorhombic & Space Group & Cmc21 (36) & $\mathbf{a}$ & 18,067 & $\boldsymbol{\alpha}$ & 90 \\
\hline Lattice & End-centered & Density & - & b & 20,284 & $\boldsymbol{\beta}$ & 90 \\
\hline Lambda & 1,5406 & Pattern & I & c & 7,491 & $\boldsymbol{\gamma}$ & 90 \\
\hline
\end{tabular}

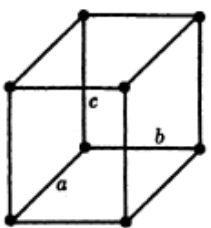

Primitive $(\mathrm{P})$

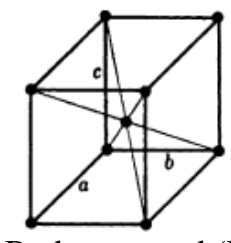

Body centered (I)

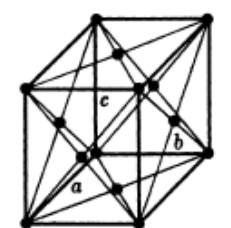

Face centered $(\mathrm{F})$

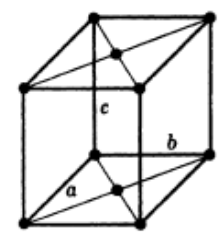

End centered $(\mathrm{C})$

Fig.6. Bravais lattice of orthorhombic.

If the $\mathrm{XRD}$ peaks of $\mathrm{ZB}$ is compared to that ICDD 49-0924, then it can assumed that ZB belong to be a mineral mordenite group. The crystal system should be orthorhombic, lattice of end-centered, and space group of $\mathrm{Cmc} 21$ (36). In this case, there are 4 possible Bravais lattice of orthorhombic crystal system i.e. simple or primitive $(\mathrm{P})$, body centered (I), end centered $(\mathrm{C})$, and face centered $(\mathrm{F})$ as shown in Fig. 6 (Cullity, 1987). There are also exist three unequal axis at right angles, $a \neq b \neq c, \alpha$ $=\beta=\gamma=90^{\circ}$. Supandi (1999) reports that crystal structure of Bayah zeolite may contains two crystal systems, there are crystal monoclinic with space group $\mathrm{C} 2 / \mathrm{m}$ and crystal orthorhombic with space group of $\mathrm{CmCm}$. Supandi conclusion based on a calculation by a refinement Rietan method. Perhaps, the conclusion was correct, because the XRD spectrum of our sample ZB didn't merely follows the ICDD orthorhombic crystal system. Therefore, it can be assumed that our ZB sample may comprises a mixture of mineral mordenite and clinoptilolite.

\section{Chemical Analysis}

Table 6 show some metal oxide that containing in $\mathrm{ZL}$ and $\mathrm{ZB}$ as it was compared to others results.

Table 6. Metal Oxide in Zeolite

\begin{tabular}{|l|c|c|c|c|}
\hline \multirow{2}{*}{$\begin{array}{c}\text { Metal } \\
\text { Oxide }\end{array}$} & \multicolumn{4}{|c|}{ Percentage of Metal Oxide (\%) } \\
\cline { 2 - 3 } & $\mathbf{Z L}$ & Current Result & \multirow{2}{*}{$\begin{array}{c}\text { *PT Minamata } \\
\text { Clinoptilolite }\end{array}$} & $\begin{array}{c}\text { *Supandi } \\
\text { Mordenite }\end{array}$ \\
\cline { 2 - 3 } & 0,94 & 0,80 & 1,29 & 1,46 \\
\hline $\mathrm{Fe}_{2} \mathrm{O}_{3}$ & 0,63 & 0,98 & 0,75 & 0,20 \\
\hline $\mathrm{Na}_{2} \mathrm{O}$ & 0,70 & 0,67 & 1,54 & 2,81 \\
\hline $\mathrm{K}_{2} \mathrm{O}$ & 0,52 & 0,42 & 1,31 & 2,36 \\
\hline $\mathrm{CaO}$ & &
\end{tabular}

*The comparison is assumed that the zeolite comes from the same area, but not exactly the same sample. 
Table 7. Zeolite Filter Performance

\begin{tabular}{|l|c|c|c|c|c|c|c|c|}
\hline \multirow{3}{*}{ Filter } & \multicolumn{8}{|c|}{ Heavy Metal Contents (gram) } \\
\cline { 2 - 9 } & \multicolumn{2}{|c|}{ Pb } & \multicolumn{2}{c|}{ Fe } & \multicolumn{2}{c|}{ Mg } & \multicolumn{2}{c|}{ Ca } \\
\cline { 2 - 9 } & $\mathbf{X}$ & $\mathbf{Y}$ & $\mathbf{X}$ & $\mathbf{Y}$ & $\mathbf{X}$ & $\mathbf{Y}$ & $\mathbf{X}$ & $\mathbf{Y}$ \\
\hline Zeolit Lampung & 19,07 & 15,33 & 0,49 & 0,43 & 0,28 & 0,24 & 0,94 & 1,02 \\
\hline Zeolit Banten & 19,07 & 10,33 & 0,49 & 0,18 & 0,28 & 0,21 & 0,94 & 0,97 \\
\hline Activated ZL & 19,07 & 8,86 & 0,49 & 0,26 & 0,28 & 0,22 & 0,94 & 0,84 \\
\hline
\end{tabular}

Caution : $\mathrm{X}=$ before filtering, $\mathrm{Y}=$ after filtering.

As can be seen in Table 6, the metal oxides that containing in ZL were almost nearly similar that containing in ZB. But it was not in case of the results that reported by others. The different may caused by the different of analysis method or different sample itself.

The result of Croatian zeolite of clinoptilolite was also different (Cerjan, et al., 2004). Therefore, the different origin of zeolite may provide different characteristics and chemical containment. For the reason, the characterization of natural zeolite became very important, before it's planned to be utilized for specific purpose.

\section{Zeolite Filter Performance}

Table 7 shows the zeolite filter performance. It can be seen in Table 7 , that activated ZL was found to be the best for filtering heavy metal of $\mathrm{Pb}$. In this case, original solutions that contain 19.07 gr could be reduced to be 8.86 (almost 50\%). On the other hand, ZL and ZB could be able to reduce only smaller i.e. it is reduces to be 15.33 and 10.33 , respectively. In case of $\mathrm{Fe}, \mathrm{ZB}$ shows the best as compared to that $\mathrm{ZL}$ and activated $\mathrm{ZL}$ i.e. it can reducing $\mathrm{Fe}$ from $0.49 \mathrm{gr}$ to 0.18 gr, whereas ZL and activated ZL could reduce only 0.43 gr and 0.26 gr, respectively. All kind of zeolite (ZL, ZB, and activated ZL) was found to be worse to reduce $\mathrm{Mg}$ and $\mathrm{Ca}$. Even more $\mathrm{Ca}$ became higher in case of $\mathrm{ZL}$ and $\mathrm{ZB}$ performance. The results indicate that activated zeolite became very important to design an appropriate application of natural zeolite.

\section{CONCLUSION}

Two types of natural zeolites i.e. originally from Lampung (ZL) and Bayah, Banten (ZB) have been characterized by XRD method. It may be concluded that ZL was belong to clinoptilolite mineral with monoclinic crystal structure and $\mathrm{ZB}$ was belong to mordenite mineral with orthorhombic crystal structure.

The ZB however may have a mixture composition of mordenite and clinoptilolite mineral. The chemical activation of natural zeolite was important to improve the performance of zeolite.

Different origin and different sample of zeolite provide different zeolite character. Therefore the caharacterization of natural zeolite became very important for further design application of zeolite.

\section{ACKNOWLEDGMENT}

The authors gratefully acknowledge the financial support that provide by the University Research Council (Lemlit) UIN Jakarta. Acknowledgment is also directed to Mr. Maryoto, senior technician of Center for Integrated Laboratory (PLT) UIN for assistant in chemical analysis, Ms. Nita for sample preparation, and Mr. Sugianto, Director PT Minatama for supplying zeolites. Special thank go to Dr. Jaenal for fruitful discussion.

\section{REFERENCES}

B.D. Cullity. (1978) Element of X-Ray Diffraction (Second Edition), Addison-Wesley Publishing Company Inc., California, USA.

Berrin Tansel. (2008). New Technologies for Water and Wastewater Treatment: A Survey of Recent Patents. Recent Patents on Chemical Enggineering, 1, p.17-26.

Cerjan-Stefanović, S., Siljeg, M., Bokić, L., Stefanović, B., and Koprivanac, N. (2004). Removal of Metal-Complex Dyestuffs by Croatian Clinoptilolite, 14th International Zeolite Conference, 25-30 April 2004, Cape Town, South Africa. 
Dr. Ir. Kaseno, M.Eng. (1999) Teknologi Membran: Prinsip Dasar Pembuatan dan Aplikasi, Workshop Nasional Pengembangan Teknologi Membran dan Aplikasinya di Indonesia, 31 Agustus 1999, BPPT, Jakarta, Indonesia.

Drew Chemical Corporation (1967). Water Pretreatment, United States, Filler Corporation, New Jersey.

Ir. Hadiati B. Haryono. (1999) Overview Perkembangan Teknologi membran di Indonesia, Workshop Nasional Pengembangan Teknologi Membrane dan Aplikasinya di Indonesia, 31 Agustus 1999, BPPT, Jakarta, Indonesia.

Ir. Lanjar. (1999) Keunggulan Penggunaan Membran Hibrid. Workshop Nasional Pengembangan Teknologi Membrane dan Aplikasinya di Indonesia, 31 Agustus 1999, BPPT, Jakarta, Indonesia.

Jie Liu, Xiao Bo CHEN, Wei Shen YANG, Ai Sheng HUANG, Li Wu LIN. (2002) Preparation of Zeolite-metal Composite Membrane, Chinese Chemical Letters Vol. 13, No. 2, pp 183-184.

P. Worathanakul, and P. Kongkachuichay. (2008) New SUZ-4 Zeolite Membrane from Sol-Gel Technique, International Journal of Chemical and Biomolecular Engineering $1: 3$.

Supandi (1999) Karakterisasi Struktur Zeolit Alam Bayah Menggunakan Program Rietan (Thesis Magister Sciences), Program
Pacsasarjana, Universitas Indonesia, Prodi Material Sciences Jakarta.

Takao Kokugan. (1999) Development of Membrane Preparation Technology in Japan. Workshop Nasional Pengembangan Teknologi Membrane dan

Thamzil Las (1989) Use of Natural Zeolites for Nuclear Waste Treatment (Ph.D. Thesis), The University of Salford, United Kingdom.

Thamzil Las, Husen Zamroni. (1999) Penggunaan Zeolit dalam Bidang Industri dan Lingkungan Hidup, disajikan dalam Seminar Ikatan Zeolit Indonesia (IZI), 14 September 1999, Jakarta.

V. Stankov-Jvanovic, T. Pecev, V. Mitic, J. Perovic, B. Jovanovic. (2003). Natural Zeolite Application in Textile Wastewater Treatment. Journal of Environmental Protection and Ecology, 4, No.3, p.700-703.

Valentine Valtcher. (2009) Veryfied Synthesis of Zeolite Materials: Preparation of Zeolite Membrane, Universite de Haute Alsace, France. $\quad$ http://www.izaonline.org/synthesis/VS_2ndEd/Membrane. htm (05/26/2009 12:41 PM).

Xiaochun $\mathrm{Xu}$, Weishen Yang, Jie Liu, Liwu Lin, Norbert Stroh, Herwig Brunner. (2004) Syntesis of NaA Zeolite Membrane on a Ceramic hollow Fiber, Journal of Membrane science 229, p.81-85. 